\title{
Wheel of Hope as Media Creates Hope Become Reality and Becomes a Parameter Success in Realizing Dreams: A Case Study at Darul Inayah Cisarua Orphanage Bandung
}

\author{
Anas Anwar Nasirin and Taufik Ampera
}

\begin{abstract}
It is certain that everyone has hope. People who have no hope, life will feel empty and meaningless. Hope can be interpreted as the basic form of belief in something desired, will be obtained, or an event will bear fruit in the future. Hope is a term that has been widely described by experts in the field of psychology. Hope that is not in accordance with reality will cause problems. The problem arises when there is a discrepancy between the expectations (das sollen) with the reality (das sein). With the tool everyone will always strive to realize his expectations through the visualization of the expectations that are implemented through the wheels of hope. The wheel of hope as a strategic tool in realizing dreams becomes a reality. The case study research model in this research activity will be applied intensively, in detail, and deeply in observing the activity of each individual when pouring his dreams into a hope, then through the visualization of hope that individual activity is observed through the ladder of success until each individual is able to realize the reality of his dreams. Activities performed on one orphanage in the area of Bandung by giving explanations about the writing of dreams or targets on the wheel of hope which will then be a parameter whether the dream or target is achieved or not.
\end{abstract}

Index Terms-Wheel of hope, dream, parameter, target.

\section{INTRODUCTION}

The theory of hope has been developed by C.R. Snyder for years. According to Snyder, hope is the ability to plan the way out in an effort to achieve goals despite the obstacles, and make motivation as a means of achieving goals [1]. In general it can be concluded the sense of hope is a positive mental state in a person with the ability he has in an effort to achieve goals in the future. The factors that influence the objectives of the expectations and behaviors directed by Snyder, among others; (1) How much is the value of the outcome, (2) The planned way out can be ascertained to the appropriate outcomes and desires on how their effectiveness will succeed on something produced, and (3) The self-concept and how effectively one will follow the way in reaching the goal [1]. While the factors that affect expectations in his research suggests, among others; (1) Social Support [2]. According to Raleig, hope has a close relationship with social support, Social support for hope is a form of interpersonal ability where the social environment

Manuscript received April 12, 2018; revised October 16, 2018. This study was supported in part by Faculty of Cultural Science, Padjadjaran University Jalan Bandung-Sumedang km. 21, West Java, Indonesia.

Anas Anwar Nasirin and Taufik Ampera are with the Departement History, Faculty of Cultural Science, Padjadjaran University Jalan Bandung-Sumedang km. 21, West Java, Indonesia (e-mail: anwarnasirinanas@gmail.com, aufik.ampera@unpad.ac.id). provides assistance in the form of emotional attention, giving information and appreciation [3]. For example, spending time with family (2) Religious Faith, religious faith affect expectations in the form of individual behavior. So that every behavior carried out must be in accordance with the beliefs adopted, if it is not appropriate it will cause concern for the individuals; and (3) Control. Maintaining control is one part of the concept of hope. It is certain that everyone has hope. People who have no hope, life will feel empty and meaningless. Hope can be interpreted as the basic form of belief in something desired, will be obtained, or an event will bear fruit in the future. Hope is a term that has been widely described by experts in the field of psychology. Averill et al., Describes expectations as emotions directed by cognition and influenced by environmental conditions [4]. Stotland and Gottschalk each describe hope as a desire to achieve goals, Stotland emphasizes the importance and possibilities of achieving goals, while Gottschalk describes the positive forces that drive one to work through difficult circumstances [4]. Staat sees hope as an expectation that interacts with expectations to realize the possibilities and influence the goals achieved [4]. Based on the four views of experts above, then hope can be understood as desire, ideals, or goals of someone accompanied by emotions and directed by cognition that is influenced by environmental conditions that will bear fruit.

Hope that is not in accordance with reality will cause problems. The problem arises when there is a discrepancy between the expectations (das sollen) with the reality (das sein). Not a few event or events must be faced and it did not correspond to the wishes or expectations, all of which occur sometimes very contrary to the expectations that have been built, sometimes even a plan that is ripe forced to fail at the last second. Of course it will make a problem sometimes cause a sense of laughter even despair. The problem will eventually become a social problem. Social problems are a condition undesirable by as large a group of people. Social problems can threaten and endanger social life.

So that an expectation is not in vain and did not become a social problem, it is necessary to design to realize hope. Design achievement of hope will be a tool in an effort to achieve a reality. However, until now there has not been found a design to realize expectations into a reality. To resolve the issue, it is necessary to do some research related to tools that can be used to create an expectation in reality. So this research will design a tool that can realize the expectations become reality. 


\section{RESEARCH PURPOSES}

Research objectives as follows:

1. Reveals people's perceptions of expectations that must come true.

2. Explain the problems faced by someone if there is a mismatch between expectations with reality.

3. Designing and testing tools that can realize expectations become a reality.

\section{BENEFITS}

This research will provide benefits to the community regarding the tools that can be applied to realize a hope becomes a reality. The tool will motivate every individual to try to realize his expectations.

With the tool everyone will always strive to realize his expectations through the visualization of the expectations that are implemented through the wheels of dreams. The wheel of hope as a strategic tool in realizing expectations becomes a reality. The wheel of hope has the tools to control and control every activity undertaken by each individual in realizing his expectations.

\section{METHOD}

The method used in this research is qualitative method. Qualitative research believe that truth is dynamic and can be found only through the study of people through their interaction with their social situation [5]. Qualitative research examines participants perspectives with strategies that are interactive and flexible. Qualitative research is aimed at understanding social phenomena from the point of view of participants. Thus the meaning or understanding of qualitative research is the research used to examine the condition of natural objects in which researchers are key instruments [6].

The research model used is case study. The Case Study is derived from the English translation "A Case Study" or "Case Studies". The word "Case" is taken from the word "Case", is defined as 1). "Instance or example of the occurance of sth., 2) "Actual state of affairs; situation ", and 3). "Circumstances or special conditions relating to a person or thing". In sequence the meaning is 1). example of something, 2). the actual conditions of circumstances or situations, and 3). environment or certain conditions about people or something [7]. From the definition of the definition can be concluded that the Case Study is a series of scientific activities conducted intensively, in detail and in depth about a program, event, and activity, whether at the individual level, a group of people, institutions, or organizations to gain in-depth knowledge of events the. Typically, the selected event hereinafter referred to as the case is the real-life event, which is in progress, not something that has passed.

The case study research model in this research activity will be applied intensively, in detail, and deeply in observing the activity of each individual when pouring his dreams into a hope, then through the visualization of hope that individual activity is observed through the ladder of success until each individual is able to realize the reality of his dreams.

The research stages will be conducted in accordance with the procedure below:

1. Library research (library research) is utilizing the library as a means of collecting data, by studying the books as reference materials related to this research. The achievement strategy at this stage is to conduct literature study with the output target in the form of data related to reference materials, theories, and various approaches related to the research to be conducted.

2. Field research (Field Work Research) is a research activity that the authors do by dealing directly with the object under study in the field, the strategy of achievement at this stage is done through the following activities:

a. Observation, which is conducting direct observation of the field about the condition and condition of the object of research to obtain the necessary data in this study, the expected output of the condition and condition of the object of research with various problems it faces.

b. Interview, which is held question and answer with respondent to get information directly, the expected output of data related to individual expectation in their life.

c. Observation; this step is done to observe each object of research in designing the dreams, visualize his expectations, and realize his expectations. Targeted outcomes are in the form of data describing the effectiveness of the tool used as a media research, as well as data related to the realization of individual expectations and their behavior.

3. Data processing which includes, categorization of data and data analysis based on the researcher's objective perception. Achievement strategy at this stage is done by describing the existing data in a simple, detailed, intact and interactive. The targeted outcomes are the results of the analysis of the effectiveness of the wheel of hope sheets used by each individual in realizing his expectations into a reality.

4. Drawing conclusions. The conclusions are formulated based on the results of the objective analysis of the collected data. Target achievement is an objective and structured research objective.

\section{Discussion AND ANALYSIS RESUlt}

The study involved 34 respondents of the age range of 17 and 18 years at Darul Inayah Cisarua Orphanage, West Bandung regency in October 2017 until May 2018. The research begins with sharing about motivation and the importance of having hope as the key to realizing reality. The expectations formulated are inventoried on the hopper sheet, which contains the target achievement goal columns for a certain period of time, beginning in 2017. However, in this study, each respondent is trying to formulate his expectations until 2030, in accordance with the achievements of SDGs (Sustainable Develovment Goals). By 2030 the age of respondents in the study has reached the age range of 30 and 31 years, so these respondents in 2030 are predicted as part of Indonesia Demographic Bonus that reaches $64 \%$ of the projected population of 297 million people [8].

In the middle of the hope wheel sheet is included the words I Want Me Able, this word works so that every individual has a hope of success, so that each individual will try as hard as possible to realize his expectations, every individual is 
required to have the will. The will is a promise to oneself, which gives great power [9]. A power that every human being will help him become a winner who overcame his ego and pushed his dream into reality. Then the ability is the capacity of individual ability in doing a work that comes from the consciousness of the individual self assessment [10]. Thus, it can be believed that when individuals already have the will, it will arise a sense of ability. In the bottom column of the hope wheel sheet there is a description of the effort that must be done as an effort to realize the expectations and become parameters to realize the dream.

The results of the study related to the measurement of individual expectations show three categories of successful expectations: Success Education (SP), Success Meets Desire (SMK), and Successful Education and Success Meets Desire (SPSMK).

1. Education Success Expectation (SP) is the hope of individuals in achieving rank 1, memorized Al-qur'an 1 juz, proficient in English, memorized 40 hadith, and can finish reading 2 books in one month. From 34 respondents as many as 26 people $(76.5 \%)$ of respondents have hope of success in this field. 24 respondents $(71.0 \%)$ have fulfilled their wishes with the media application of the hope wheel sheet in memorizing one verse of Al-qur'an every day, until the end of the 24th research the respondent has memorized 240 verses of Al-Qur'an. In addition, the 24 respondents have also fulfilled their wish to finish reading the book according to the target. While 2 other respondents $(6.00 \%)$, have not been able to realize their expectations by reason of having busy in organizing in school and other activities.

2. Successful Expectations of Success (SMK), is the hope of every individual to fulfill desire, such as want to buy clothes, want to meet parents, want to go for a walk, and more. Of the 34 respondents, 5 (14.7\%) who have hope in this field, have fulfilled their hopes with hard effort through the hope-sheet application. One of the efforts made by the respondent is saving with the amount of Rp 2000-5000 / day. From the results of savings that they realize their hope to have the desired goods and to fulfill other wishes.

3. Successful Expectations of Education and Expectations of Success in Desire (SPSMK) is the hope of success in the field of SP + SMK, of 34 respondents, as many as three respondents $(8.80 \%)$ have a successful expectation in this field. 2 people impainnya become reality $(5.88 \%)$, and 1 person $(2.94 \%)$ his dream has not materialized.

Based on the above data, it can be concluded that 34 students of Darul Inayah Orphanage who become respondents mostly want success in SP (76.5\%), SMK (14.7\%), and SPSMK (8.8\%). Then based on three success hope categories 31 respondents from 34 respondents $(91.0 \%)$ have realized their dreams, only 3 respondents $(8.94 \%)$ whose dreams have not been realized.

If the results of evaluation for 8 months based on the successful expectation of each respondent in 2017 produced 3 categories of hope of success, then if you follow the parameters of success expectations in 2030 as the end of the hope wheel then get two categories of successful expectations in general, namely Success Participation (SK) and Successful Society (SM). Of 34 people as many as 22 people (64.7\%) in 2030 have successful hopes for the family as they want to go to the Holy Land of Mecca with their parents, build houses for parents and others, and 12 others $(35.3 \%)$ by 2030 have successful hopes for people like wanting to build an orphanage, want to build free schools and other successful expectations.

\section{CONCLUSION}

This research was conducted at Orphanage Darul Inayah Cisarua, West Bandung regency to 34 respondents by giving explanation of the importance of having hope and hope writing on simulated wheel of hope from October 2017 until May 2018. The result of this simulation resulted three categories of successful expectation, that is Success Education (SP), Success Meets Desire (SMK), and Success Education \& Meet the Desires (SPMK). Based on three categories of successful expectation, 31 respondents $(91.0 \%)$ of 34 respondents have realized their successful expectation of hard effort through the affection of wheel of hope.

Based on the parameters of successful expectation long-term in 2030 obtained two categories of successful expectations, namely the success of Family (SK) and Success Society (SM). Therefore, based on the simulation results that have been implemented that the wheel of hope in addition to create hope into reality will also be a parameter of success to realize big dreams in the future.

\section{REFERENCES}

[1] A. Carr, Posytive Psycology: The Scienci of Happiness and Human Strengths, 2nd ed. New York: Brunner-Routledge, 2011, pp. 90-92.

[2] C. M. Weil, "Exploring hope in patients with end stage renal deisea on chronic hemodialysis," Nephrology Journal, vol. 27, no. 2, pp. 219-223, 2000.

[3] R. Jacoby and G. Keinan, Between Stress and Hope: from a Disease-Centered to a Health-Centered Prespective, United States of America: Praeger Publisher, 2003, p. 97.

[4] S. J. Lopez and C. R. Snyder, Oxford Handbook of Positive Psychology, Oxford University Press, 2009, p. 487.

[5] S. Danim, Menjadi Peneliti Kualitatif, Bandung: Pustaka Setia, 2005, p. 32.

[6] Sugiyono, Memahami Penelitian Kuantitatif Kualitatif dan $R \& D$, Bandung: Alfabet, 2017, pp. 6-8.

[7] Oxford Dictionary Advanced Learner's Dictionary of Current English, 3rd ed. 1989, p. 173

[8] B. H. T. U. Kepala, Bonus Demografi 2030-2040: Strategi Indonesia Terkait Ketenagakerjaan Pendidikan, Jakarta: Kementerian PPN/Bappenas, 2017.

[9] A. Fauziyah, Dasyatnya Kemauan, Jakarta: Elex Media Komputindo, 2016, pp. 37-44.

[10] S. Robbin and P. Judge, Prilaku Organisasi, Jakarta: Salemba Empat, 2007, p. 57.

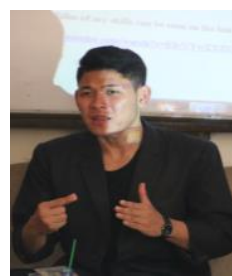

Anas Anwar Nasirin was born in Tasikmalaya, West Java, Indonesia, on April 25, 1997. He is currently completing his bachelor's degree program in history studies program in Faculty of Cultural Sciences, Padjadjaran University. $\mathrm{He}$ is very interested in the field of history, motivation, and study of Indonesian migrant workers.

During his term of college he has produced many works and awards for example, the work entitled "Confidence Can Beat Everything" (As the first champion of National Inspired Student Stories at Exist Fair 2017 SME Research \& Reasoning Exist Jambi University), "Sweetness of Life Feels After Tired of Fighting" (As National Student Inspiration Story 3rd Winner at Scientific Meeting of National Bidikmisi Students at Mataram University, Lombok, Indonesia 2017), Author of "Kepingan Peristiwa Sejarah Indonesia" in 2016 with fellow students of History Study Program of Padjadjaran University, 100 
Best Writers from 1784 Author of the Work "Analysis of Energy Resilience Issues: Youth Action Solutions Enforcement of Indonesian Enegi's Resistance" on the "Youth Writing" Youth Guard Competition NasDem 2018, And escaped the abstract of the work "Ignatian-Based Teaching Method as a Solution for Improving Teacher's Competence: A Case Study at Mts Darul Inayah Cisarua West Bandung" at the Indonesia Student Researcher Festival (ISRF 2018) Universitas Pendidikan Indonesia.

Mr. Anas Currently serving as an officer and stap HRD (human resources department) radio unpad since 2016, And once a culture and tourism ambassador Jajaka Sukapura Tasikmalaya regency in 2016.

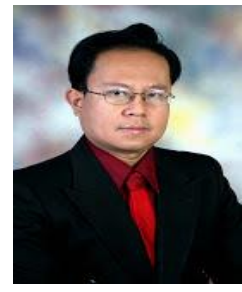

Taufik Ampera was born in Karawang, West Java, Indonesia, on March 28, 1966. He completed the undergraduate program at Faculty of Letters Universitas Padjadjaran, Indonesia, and the S2 (magister) at Gadjah Mada University Yogyakarta, Indonesia. He is currently completing a doctoral program at the graduate program of the Faculty of Humanities, Padjadjaran University. He is a lecture at the Departmen Literature of Padjadjaran
University, functional position (academic grade) as an associate professor $\mathrm{He}$ is interest in the fields of folklore skills, children's literature and adolescent literature.

$\mathrm{He}$ is very actively writing proven on several books and research publications. For example Dongeng Kaulinan: Kumpulan Sajak Sunda Pikeun Barudak (Tale of the Game: A collection of Sundanese poems for children), 2017; Katulah Ku Polah Sorangan (Woe for His Own Deeds) 2017; Literature Teaching; Technique for Teaching Children's Literature-Based Activity, 2010; The Most Popular Sundanese Folklore; Myth, Legend, and Tales, 2011; Language in Communication, 2013 Dictionary of Health Terms in Sundanese Culture, 2013. Culture of Animal Husbandry in Cikeusal Tasikmalaya Village, 2016. Publication of articles in 2017; Specific Features and Language Components of English Used by EFL Learners in Sundanese Cultural Context: A Case in a Paper Presentation Class published Atlantis Press Volume 110. The Traditional Art of Terebang Gebes in "Mikanyaah Munding” Culture on Stage Journal Volume 27.

Currently Mr. Taufik serves as a research manager, community service (CS), innovation, and cooperation at Faculty of Cultural Sciences, Padjadjaran University, Indonesia. 